\title{
Freshwater quality of a stream in agricultural area where organic compost from animal and vegetable wastes is used
}

\section{Qualidade da água de um córrego em área agrícola onde é usado composto orgânico de resíduos animais e vegetais}

\author{
Luciana Maria Saran ${ }^{1 *}$, Aylan Kener Meneghine ${ }^{1}$, Amanda Schimidt Célico ${ }^{1}$, \\ Daniel Guariz Pinheiro' ${ }^{1}$, Lucia Maria Carareto Alves ${ }^{1}$
}

\author{
'Universidade Estadual Paulista/UNESP, Departamento de Tecnologia, Jaboticabal, SP, Brasil \\ *Corresponding author: Imsaran@fcav.unesp.br \\ Received in September 26, 2016 and approved in February 6, 2017
}

\begin{abstract}
Organic compost from biomass residues constitutes a viable alternative for partial or total replacement of mineral fertilizers for growing vegetables. This study evaluated the effects of compost on the water quality of a stream used mainly for irrigation of agricultural crops cultivated in nearby soil that has been treated with organic compost produced by carcasses, animal and vegetable waste for the last ten years. We sampled water biannually for two years, 2013 and 2014, from five locations along the stream. Physical variables and some chemical variables were analyzed. We also analyzed the total number of coliforms (Escherichia coli). Bacterial populations were compared by carbon substrate consumption. Total phosphorus contents in the samples from 2014 exceeded $0.1 \mathrm{mg} \mathrm{L}^{-1}$. The concentrations of other chemical species analyzed and the results for the physical variables were in accordance with the expected values compared with national and international water quality standards. The environment showed differential carbon source consumption and a high diversity of microorganisms, but our results did not show any evidence that the applied compost is changing the microbial population or its metabolic activity. This study shows that the use of the organic compost in agricultural areas seen does not negatively influence the quality of surface water in the study area. These results are important because the process of composting animal and vegetable waste and the use of compost obtained can be an alternative sustainable for adequate destination of these wastes.
\end{abstract}

Index terms: EcoPlate; carcasses and animal waste; agriculture; surface water; composting.

\section{RESUMO}

Composto orgânico produzido a partir de biomassa residual constitui uma alternativa viável para a substituição parcial ou total de fertilizantes minerais no cultivo de hortaliças. Neste estudo foram avaliados os efeitos do composto, sobre a qualidade da água de um córrego, usado principalmente para a irrigação de culturas agrícolas cultivadas em solo nas proximidades, tratado nos últimos dez anos com composto orgânico produzido a partir de carcaças, resíduos animais e vegetais. Amostras de água foram coletadas semestralmente, em 2013 e 2014, em cinco pontos ao longo do córrego. Foram analisadas variáveis físicas, algumas variáveis químicas e o número total de coliformes (Escherichia coli). As populações bacterianas foram comparadas pelo consumo de substratos de carbono. Os teores de fósforo total nas amostras de 2014 ultrapassaram 0,1 mg L-1. As concentrações das demais espécies químicas analisadas e os resultados para as variáveis fisicas ficaram de acordo com valores estabelecidos em normas nacionais e internacionais de qualidade de água. O ambiente mostrou consumo diferencial de fontes de carbono e grande diversidade de micro-organismos, mas os resultados não mostraram qualquer evidência de que o composto aplicado seja o fator responsável pela alteração da população microbiana ou sua atividade metabólica. Este estudo mostra que o uso do composto orgânico em áreas agrícolas parece não influenciar negativamente a qualidade da água superficial na área estudada. Estes resultados são importantes porque o processo de compostagem de resíduos animais e vegetais e o uso do composto obtido podem ser uma alternativa sustentável para o destino adequado desses resíduos.

Termos para indexação: EcoPlate; carcaças e resíduos animais; agricultura; água superficial; compostagem.

\section{INTRODUCTION}

Organic compost obtained by composting generally has a lower concentration of macro and micro plant nutrients than mineral fertilizers, and these elements are not available for immediate utilization by organisms
(Ogundare; Lajide, 2013). However, this type of compost has beneficial effects on the soil, as it can increase the organic matter thereby improving its physical properties and increasing the proliferation of microorganisms in the rhizosphere (Ogundare; Lajide, 2013). Additionally, organic compost is more economical as a source of 
nutrients than mineral fertilizers, which are responsible for increases in production costs (Weindorf; Muir; LanderoSánches, 2011; Lim et al., 2015).

Composting is a decomposition process that can be performed using different sources of organic matter, such as animal or vegetable waste, and it has been identified as one of the best methods for final disposal of carcasses or other organic waste (Cancelado et al., 2014). There are few studies highlighting the importance and impact of organic composts produced by carcasses as well as animal and vegetable waste in soil (Külcü; Yaldiz, 2014), however no studies have provided details regarding possible influences of this sort of organic compost on water quality.

Agricultural activities may influence water quality due to draining and transport of elements to waterways (Secchi et al., 2011; Jordan; Ghulam; Hartling, 2013). Furthermore, water quality is extremely important in agricultural production, mostly in the irrigated agriculture, which suffers from both natural processes and anthropogenic activities. Because high concentrations of nutrients may cause public health problems and damage to the environment, water quality diagnostics are essential (Zhao et al., 2015).

Water quality is characterized by well-known physical, chemical and microbiological parameters; however, the classical microbiological methods commonly performed do not provide any knowledge regarding the physiological capabilities of microbial communities in a sample or among several samples. In this way, the use of the Biolog EcoPlate has become an important tool to study and compare catabolic diversity among different environmental samples, such as water (Chávez et al., 2011).

Although the use of organic compost can be considered as a sustainable and low cost alternative for agricultural fertilization, their impacts are poorly documented concerning the aquatic microbial communities and the chemical and physical properties of freshwater. This work provides an evaluation of the agricultural use of organic compost produced by animal and vegetable waste on water quality through physical, chemical, microbiological and metabolic activity analyses. This study was performed in the area owned by the Rural Production Division of the São Paulo Zoo Park Foundation (FPZSP), Brazil.

\section{MATERIAL AND METHODS}

In Brazil, the Resolution $n^{\circ}$. 357/2005 of the National Council for the Environment (CONAMA) provides standards for water quality and establishes limits for physical, chemical and microbiological parameters for different classes of water resources according to their preponderant uses (Brasil, 2005). The Food and Agriculture Organization (FAO) of the United Nations has also published a document entitled "Water Quality for Agriculture" (Ayers; Westcot, 1994), which establishes guidelines for the use of water for irrigation and drainage based on reported experience gained from farm areas throughout the world, mostly from irrigated agriculture in the Western United States. Despite their peculiarities, both are equally important to water quality monitoring and both aim to protect water resources for multiple sustainable uses. Table 1 summarizes the thresholds recommended by CONAMA resolution 357/2005 (for the Class 2 freshwater quality) and by FAO (for water used in irrigation).

\section{Description of study site}

The study was carried out on the farm of the São Paulo Zoo Park Foundation (FPZSP), located at Araçoiaba da Serra - São Paulo (Brazil). This agricultural property is responsible for production of most of the food served to the animals of the Zoo park and Zoo Safari. Since 2004, the park has produced organic compost made by solid waste from Zoo Park activities, including animal and vegetable residues. These materials are composted in concrete chambers followed by stabilization in windrows.

The bacterial populations of the compost were studied using a metagenomic approach (Martins et al., 2013). This work showed high bacterial diversity in compost that can fully account for the observed biomass degradation. The organic compost that was produced has been applied on the zoo farm at a rate of $200 \mathrm{t} \mathrm{ha}^{-1}$ after ground preparation at an agricultural site that produces vegetables for animal feed at the same zoo. Furthermore, mineral fertilizers (superphosphate, potash, borax and ammonium sulfate) have also been applied to the vegetable garden to supply specific nutritional requirements, depending on the planted crop. Irrigation of the vegetable garden is supplied by a freshwater stream (called the Ribeirão do Lajeado) located $30 \mathrm{~m}$ from the area of vegetable cultivation.

The stream analyzed for this study, Ribeirão do Lajeado, has an average elevation of $637 \mathrm{~m}$ and belongs to the river basin area of the Sorocaba and Medium Tietê rivers. This stream crosses the area of the zoo farm near the vegetable gardens and may be influenced by the agricultural activities carried out there as well as by the agricultural activities of other rural properties along the stream. The water resource under study has mainly been used for vegetable irrigation and the preservation of aquatic life. Ribeirão do Lajeado stream composes to the Unit of Management of Water Resources-10 (UGRHI-10) of 
the São Paulo State and according to the Environmental Company of the State of São Paulo (CETESB), the Ribeirão do Lajeado stream is class 2 .

\section{Sample collection and processing}

Water sampling was carried out four times in two years at five distinct points: two in $2013(04 / 20 / 13$ and 09/20/13) and two in 2014 (05/05/14 and 09/08/14). We designate sampling events as follows: $\mathrm{C} 1$ (first collection), $\mathrm{C} 2$ (second collection), C3 (third collection) and C4 (fourth collection). The Figure 1 displays the sampling points, P1 is a control point upstream of the vegetable garden where the compost is used. It was adopted as control because it is positioned before the vegetable garden. Access to the source or points upstream of $\mathrm{P} 1$ was not possible. $\mathrm{P} 2$ is in middle place and behind the water collection site for irrigation; P3 is close to the water collection site for irrigation; $\mathrm{P} 4$ and P5 are located downstream of the vegetable garden area.

Samples were collected up to a depth of $30 \mathrm{~cm}$ from the water surface, adopting proper procedures for sampling, storage and preservation of inorganic nonmetallic constituents and aggregate organic constituents as described in the Standard Methods for the Examination of Water and Wastewater (Baker, 2005). We sampled three liters of freshwater from each point, and all the measurements were performed in triplicate. Water samples for microbial activity analysis and other microbiological analysis were collected in sterilized amber glass vials, which were then transported to the laboratory for storage at 4 to $8{ }^{\circ} \mathrm{C}$ until their use.

The amount of rainfall in the region during the years of samplings and in the days near the collection periods is shown in Figure 2. This figure shows total monthly rainfall over the year and the diary precipitation 15 days before sampling, according to data from the Brazilian National Institute of Meteorology (INMET).

Rainfall occurred throughout the $\mathrm{C} 1$ period but not for other collections, so we characterize $\mathrm{C} 1$ as "rainy". In the three days that preceded $\mathrm{C} 2$ there was occurrence of light rain (about $20 \mathrm{~mm}$ in total). However, before that period there was no rainfall in the region for about 50 days. About a fortnight before $\mathrm{C} 3$, no rainfall was recorded, noting that in 2014, in the periods preceding these fifteen days precipitation was intense (approximately 76 to $146 \mathrm{~mm}$ ). One week before $\mathrm{C} 4$ there was precipitation in two days (10 and $23 \mathrm{~mm}$ ). However, the total rainfall in the months of June, July and August, preceding the last collection, was low (14, 27 and $28 \mathrm{~mm}$, respectively).

Table 1: Maximum values for the variables from CONAMA 357/2005 and the FAO.

\begin{tabular}{|c|c|c|c|}
\hline \multirow[b]{2}{*}{ Variables } & \multirow[t]{2}{*}{ CONAMA 357/2005 } & \multicolumn{2}{|c|}{ FAO } \\
\hline & & Ideal & Acceptable \\
\hline $\mathrm{pH}$ & $6.0-9.0$ & $6.5-8.4$ & ne \\
\hline $\mathrm{DO}\left(\mathrm{mg} \mathrm{L}^{-1}\right)$ & $>5.0$ & ne & ne \\
\hline $\mathrm{EC}\left(\mu \mathrm{S} \mathrm{cm^{-1 } )}\right.$ & ne & 700 & $700-3,000$ \\
\hline TDS $\left(\mathrm{mg} \mathrm{L}^{-1}\right)$ & 500 & $<450$ & $450-2,000$ \\
\hline Turbidity (NTU) & 100 & ne & ne \\
\hline $\mathrm{ORP}(\mathrm{mV})$ & ne & ne & ne \\
\hline $\mathrm{Cl}^{-}\left(\mathrm{mg} \mathrm{L}^{-1}\right)$ & 250 & $<142$ & $142-355\left(^{*}\right)$ \\
\hline $\mathrm{NO}_{2}^{-}-\mathrm{N}\left(\mathrm{mg} \mathrm{L}^{-1}\right)$ & 1.0 & ne & ne \\
\hline $\mathrm{NO}_{3}^{-}-\mathrm{N}\left(\mathrm{mg} \mathrm{L}^{-1}\right)$ & 10,0 & $<5$ & $5-30$ \\
\hline $\mathrm{NH}_{4}^{+}-\mathrm{N}\left(\mathrm{mg} \mathrm{L}^{-1}\right)$ & 3.7 to $\mathrm{pH} \leq 7.5$ & ne & ne \\
\hline $\mathrm{TP}\left(\mathrm{mg} \mathrm{L}^{-1}\right)$ & 0.10 & ne & ne \\
\hline $\mathrm{DRP}\left(\mathrm{mg} \mathrm{L}^{-1}\right)$ & ne & ne & ne \\
\hline Thermotolerant coliforms & 1,000 & ne & ne \\
\hline
\end{tabular}

ne: not established.

$\left.{ }^{*}\right)$ for surface irrigation.

pH: hydrogen potential. DO: dissolved oxygen. EC: electrical conductivity: TDS: total dissolved solids. NTU: nephelometric turbidity unity. ORP: oxidation-reduction potential. $\mathrm{Cl}$ : chloride. $\mathrm{NO}_{2}{ }^{-} \mathrm{N}$ : nitrite. $\mathrm{NO}_{3}{ }^{-} \mathrm{N}$ : nitrate. $\mathrm{NH}_{4}{ }^{-} \mathrm{N}$ : ammoniacal nitrogen. TP: total phosphorus. DRP: dissolved reactive phosphorus. Thermotolerant coliforms: 1,000/100 mL. 

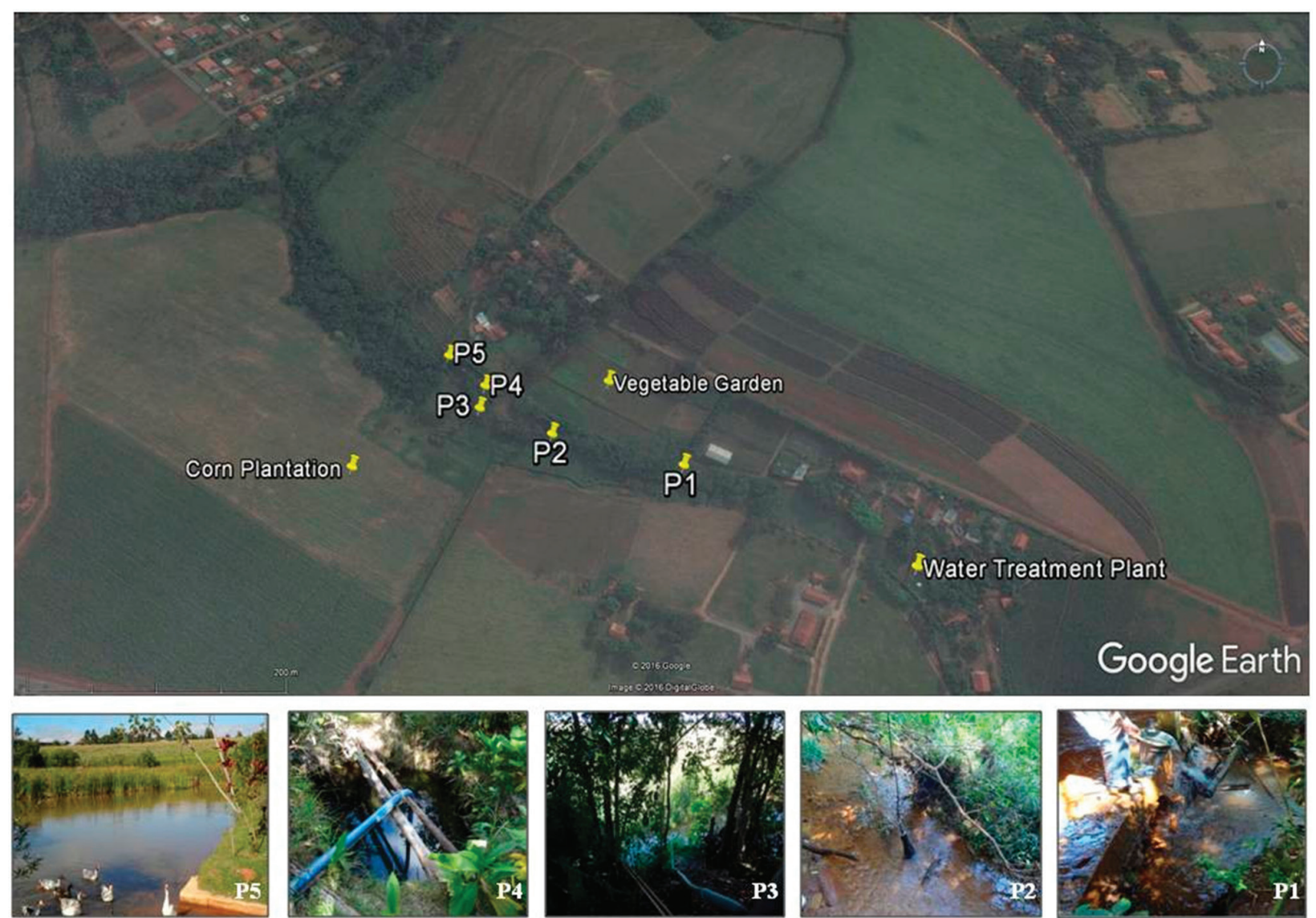

Figure 1: Image of the study site and details of the sampling points. The geographical coordinates of collecting points are: P1 $\left(23^{\circ} 34^{\prime} 48,13^{\prime \prime} \mathrm{S}-4^{\circ} 35^{\prime} 10,69^{\prime \prime} \mathrm{W}\right)$; P2 $\left(23^{\circ} 34^{\prime} 47,15^{\prime \prime} \mathrm{S}-47^{\circ} 35^{\prime} 15,04^{\prime \prime} \mathrm{W}\right) ;$ P3 $\left(23^{\circ} 34^{\prime} 46,07^{\prime \prime} \mathrm{S}-\right.$

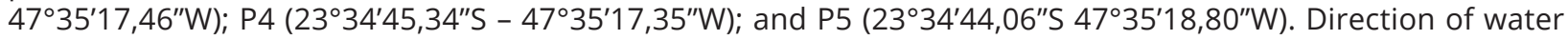
flux: from P1 to P5.

Rainfall occurred throughout the $\mathrm{C} 1$ period but not for other collections, so we characterize $\mathrm{C} 1$ as "rainy". In the three days that preceded $\mathrm{C} 2$ there was occurrence of light rain (about $20 \mathrm{~mm}$ in total). However, before that period there was no rainfall in the region for about 50 days. About a fortnight before $\mathrm{C} 3$, no rainfall was recorded, noting that in 2014 , in the periods preceding these fifteen days precipitation was intense (approximately 76 to $146 \mathrm{~mm}$ ). One week before $\mathrm{C} 4$ there was precipitation in two days (10 and $23 \mathrm{~mm}$ ). However, the total rainfall in the months of June, July and August, preceding the last collection, was low (14, 27 and $28 \mathrm{~mm}$, respectively).

The average air temperature during sampling ranged from 19.4 to $23.5{ }^{\circ} \mathrm{C}$. Mineral fertilizers were applied in the soil of the vegetable gardens three days before 2014 collections (C3 and $\mathrm{C} 4$ ).

\section{Physical and chemical variables}

The electrical conductivity (EC), dissolved oxygen (DO), $\mathrm{pH}$, oxidation-reduction potential (ORP), total dissolved solids (TDS) and turbidity were measured on site with a Horiba U-50 multiparameter probe.

The ammoniacal nitrogen $\left(\mathrm{NH}_{4}{ }^{+}-\mathrm{N}\right)$, nitrate $\left(\mathrm{NO}_{3}^{-}-\mathrm{N}\right)$, nitrite $\left(\mathrm{NO}_{2}^{-}-\mathrm{N}\right)$, total phosphorus (TP) and dissolved reactive phosphorus (DRP) were obtained using molecular spectroscopy in the visible region with a SPEC 20D spectrophotometer. The phenate method was used to quantify $\mathrm{NH}_{4}^{+}$, and a colorimetric method for measuring $\mathrm{NO}_{2}^{-}$used $\mathrm{N}$-(1-naphthyl)-ethylenediamine dihydrocloride (NED dihydrochloride) to react with an analyte. The reduction method was used to quantify $\mathrm{NO}_{3}^{-}$, and the ascorbic acid method was used for TP after digestion of water samples with sulfuric and nitric acids. 

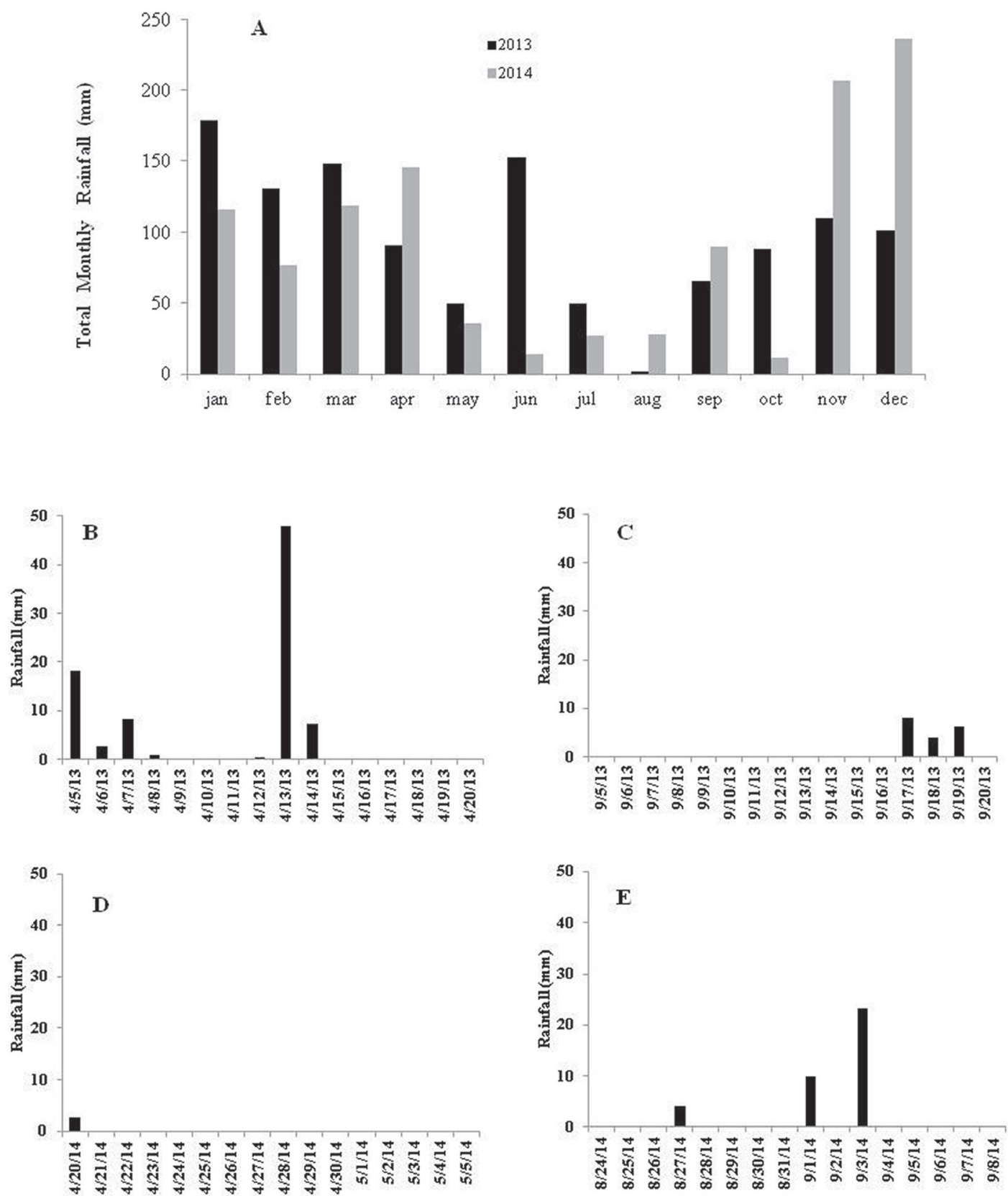

Figure 2: (A) Total monthly precipitation over the year and and the diary precipitation during the 15 days before sampling for (B) C1, (C) C2, (D) C3 and (E) C4, according to data from the Brazilian National Institute of Meteorology (INMET).

DRP was also analyzed using the ascorbic acid method after sample percolation through a $0.45 \mu \mathrm{m}$ membrane (Askew; Smith, 2005). Chloride $\left(\mathrm{Cl}^{-}\right)$was obtained by precipitation titrimetry using the argentometric method (Askew; Smith, 2005). All analyses were performed in triplicate for each variable.

\section{Microbiological parameters}

Microbiological analysis were performed using the membrane filter method to verify the total coliforms and Escherichia coli (E. coli) (method 9222B; Hunt; Rice, 2005). $100 \mathrm{~mL}$ of water per membrane were filtered, and all tests were performed in triplicate. 
To evaluate the presence of virulence genes shiga toxin (stxl and stx2) and enteropatogenic (eae), another aliquot of water samples was filtered to extract metagenomic DNA using the PowerWater DNA Isolation kit (MOBIO Laboratories, Inc.) according to the manufacturer's protocol. DNA was quantified with a NanoDrop 1000 spectrophotometer (Thermo Fisher Scientific, USA) Next, PCR was performed using primers specific for these virulence genes as described by China, Pirson and Mainil (1996), with amplicons of $388 \mathrm{bp}$ (stx1), $807 \mathrm{bp}$ (stx2) and $570 \mathrm{bp}$ (eae). PCR reactions were performed using approximately $40 \mathrm{ng}$ of DNA, 1x PCR buffer $\left[20 \mathrm{mmol} \mathrm{L}^{-1}\right.$ in Tris- $\mathrm{HCl}(\mathrm{pH} 8.4)$ and $50 \mathrm{mmol}$ $\mathrm{L}^{-1}$ in $\mathrm{KCl}$ ], $2 \mathrm{mmol} \mathrm{L}^{-1} \mathrm{MgCl}_{2}, 0.2 \mathrm{mmol} \mathrm{L}^{-1} \mathrm{DNTP}, 10$ pmol of each oligonucleotide primer, 1.0 $\mathrm{U}$ of Taq DNA polymerase and ultra-pure water to achieve a final volume of $20 \mu \mathrm{L}$. Thermal cycling was carried out according to Borges et al. (2012) using the DNA of the bacteria Escherichia coli as a positive control. Amplicons were submitted to electrophoresis in $1 \%$ agarose gel to evaluate the presence of virulence genes. The gel was analyzed with UV light in Gel Doc 1000 (Bio Rad, USA).

The microbial metabolic potential in the water was evaluated by comparing the metabolism of 31 different carbon substrates available on Biolog EcoPlate (Inc. Harward, California, USA), which contain 3 replicates of each carbon source. A $120 \mu \mathrm{L}$ sample of water from each point was deposited directly into a 96-well microtiter plate under laminar flow to avoid undesirable contamination from the environment. Then, these plates were incubated for up to $120 \mathrm{~h}$ at $27^{\circ} \mathrm{C}$ in a biological oxygen demand (BOD) incubator to prevent temporal and spatial differences. After incubation, the consumption of each substrate was evaluated by measuring the optical absorbance at $590 \mathrm{~nm}$ for each well every $24 \mathrm{~h}$. The average well color development (AWCD) was calculated according to Garland and Mills (1991). The area under the curves of absorbance development for each substrate was integrated according to Hackett and Griffiths (1997). The area under the color development profile summarizes the profile obtained throughout the incubation period in a single value for substrate $i$ and plate $k$. The substrates richness (SR), which corresponds to the total number of substrates consumed by the microorganisms, was calculated according to Ibekwe and Kennedy (1998), and the Shannon index, which accounts for richness and evenness of substrate utilization in the studied environment, was calculated as suggested by Zak et al. (1994). Hierarchical clustering of the summarized values was performed using the Euclidean distance with average linkage.

\section{Statistical Analysis}

Exploratory analysis for chemical and physical variables was conducted using SAS (SAS INSTITUTE, 2008) and R (The R project for statistical computing, 2014). ANOVA was first performed on these data, and a pairwise post hoc comparison was calculated by means of Tukey's test. Turbidity and $\mathrm{NH}_{4}{ }^{+}-\mathrm{N}$ were transformed, respectively, by $x^{-4}$ and $\sqrt{x+0.5}$. EcoPlate data processing and analysis, including normalization and clustering, were performed in the R programming environment.

\section{RESULTS AND DISCUSSION}

\section{Physical and chemical variables: spatial and temporal variability}

The arithmetic means of the variables $\mathrm{pH}, \mathrm{DO}$, ORP, turbidity, EC, TDS, $\mathrm{Cl}^{-}, \mathrm{NO}_{2}^{-}-\mathrm{N}, \mathrm{NO}_{3}^{-}-\mathrm{N}, \mathrm{NH}_{4}^{+}-\mathrm{N}$, TP and DRP for all sampled times and points are shown in Figures 3 and 4. We performed analysis of variance according to the statistical model used (Table 2), and variables that had significant differences among collections were investigated to identify the differences between pairs of collections (Table 3).

The values of $\mathrm{pH}$ varied slightly (Figure 3 ), ranging from 5.80 (C3P5) to 7.65 (C2P1). We observed near-neutral values that were within the range established by CONAMA $357 / 2005$ (Table 1). The values of DO (Figure 3) varied from 3.61 (C3P5) to $9.21 \mathrm{mg} \mathrm{L}^{-1}$ (C2P1) and for ORP, points 3, 4 and 5 presented the highest values observed (Figure 3).

Across all points, $\mathrm{pH}$ and ORP were the only variables with significant differences at the $1 \%$ significance level ( $p$-value $<0.01$ ), indicating that at least one of the averaged points differed significantly among themselves.

Among the collections, it was possible to conclude that for all variables, except DO, there were significant differences at the 5\% significance level (p-value $<0.05$ ), indicating that at least one of the averaged samples differed significantly from another. The variable $\mathrm{pH}$ differed between $\mathrm{C} 2$ and $\mathrm{C} 3$. For ORP, the average of the $\mathrm{C} 4$ results was the only collection that was significantly different from the averages of the other collections (Table 3).

Because they showed significant differences among points, $\mathrm{pH}$ and ORP were investigated to identify the differences between pairs of points (Table 4). Most aquatic organisms are very sensitive to $\mathrm{pH}$ changes, and this variable can alter metabolic activities of aquatic organisms (Brraich; Saini, 2015), but the variation 
among the samples in our study seems to be acceptable in biological system. The differences of $\mathrm{pH}$ values can not be associate with spatial position of samples in the flux of the stream none with the use of organic compost in vegetable garden. For ORP, the points P3, P4 and P5 were not significantly different, but they differed from points $\mathrm{P} 1$ and $\mathrm{P} 2$ when all samplings were averaged. According to Corcóvia and Celligoi (2012) and Shelton
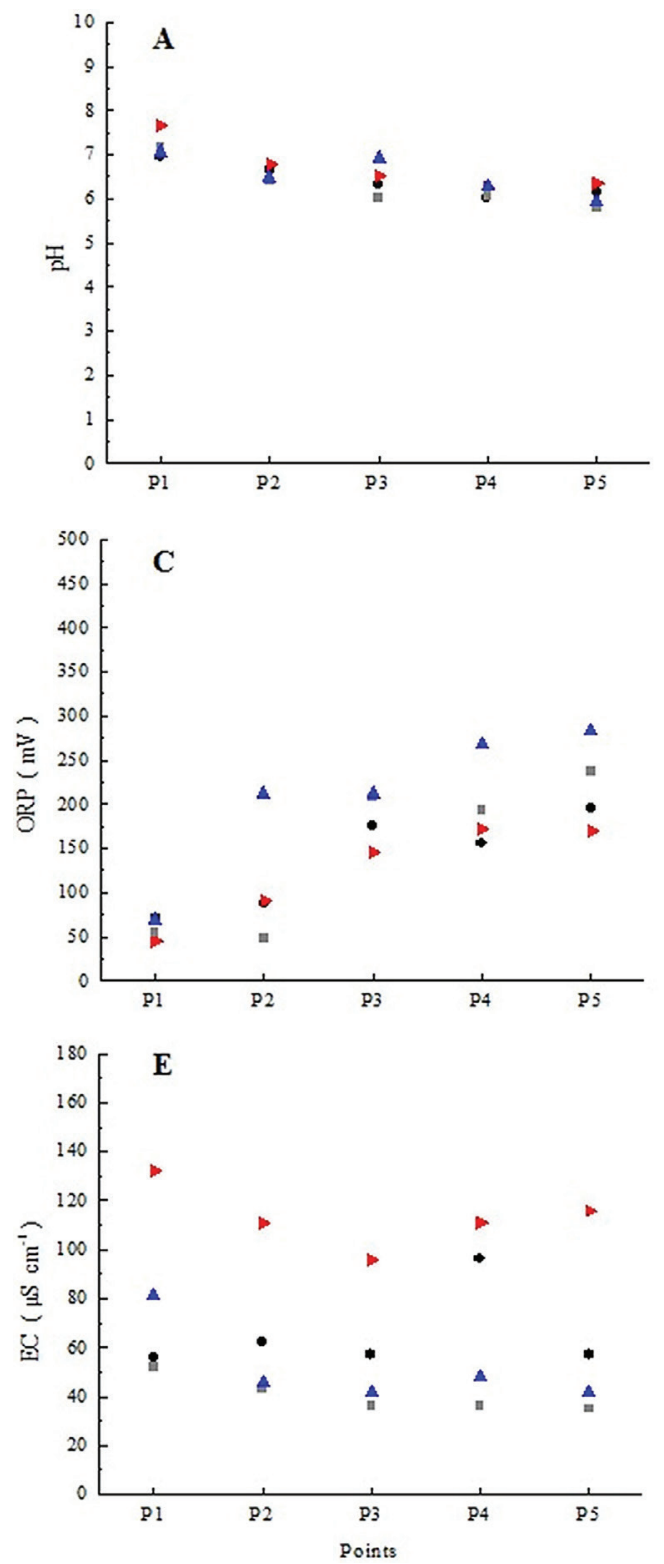

et al. (2014) in their ORP analyses of different water samples, their values were close to those obtained for the last three points in this study. In addition, the external factors that contributed most to these results were environmental pollution, exhaust gases and pesticides (Corcóvia; Celligoi, 2012).

The average values of TDS and electric conductivity (Figure 3) ranged from $23(\mathrm{C} 3 \mathrm{P} 4)$ to $75 \mathrm{mg} \mathrm{L}^{-1}(\mathrm{C} 2 \mathrm{P} 5)$ and
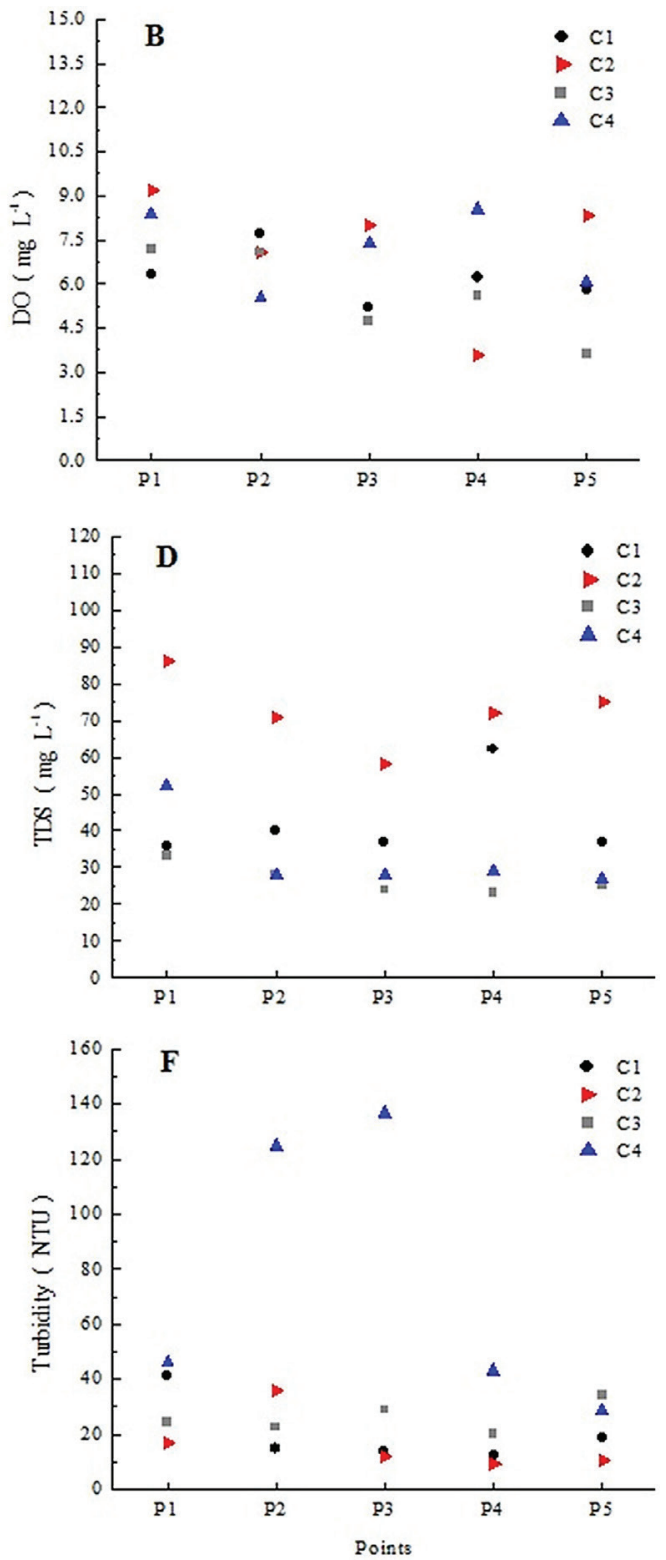

Figure 3: Arithmetic means of the following variables: (A) pH, (B) DO (dissolved oxygen), (C) ORP (oxidationreduction potential), (D) TDS (total dissolved solids), (E) EC (eletrical condutivity) and (F) turbidity. 
from 35 (C3P5) to $132 \mu \mathrm{S} \mathrm{cm}^{-1}$ (C2P1), respectively. The highest values for TDS and EC were observed for $\mathrm{C} 2$ in all sampled points and were significantly different at a 5\% significance level ( $p$-value $<0.05$ ). EC is correlated to the concentration of cations and anions in the water body and is related to the concentration of total dissolved solids (Libânio, 2010). According to Shuster et al. (2013), EC increases when the amount
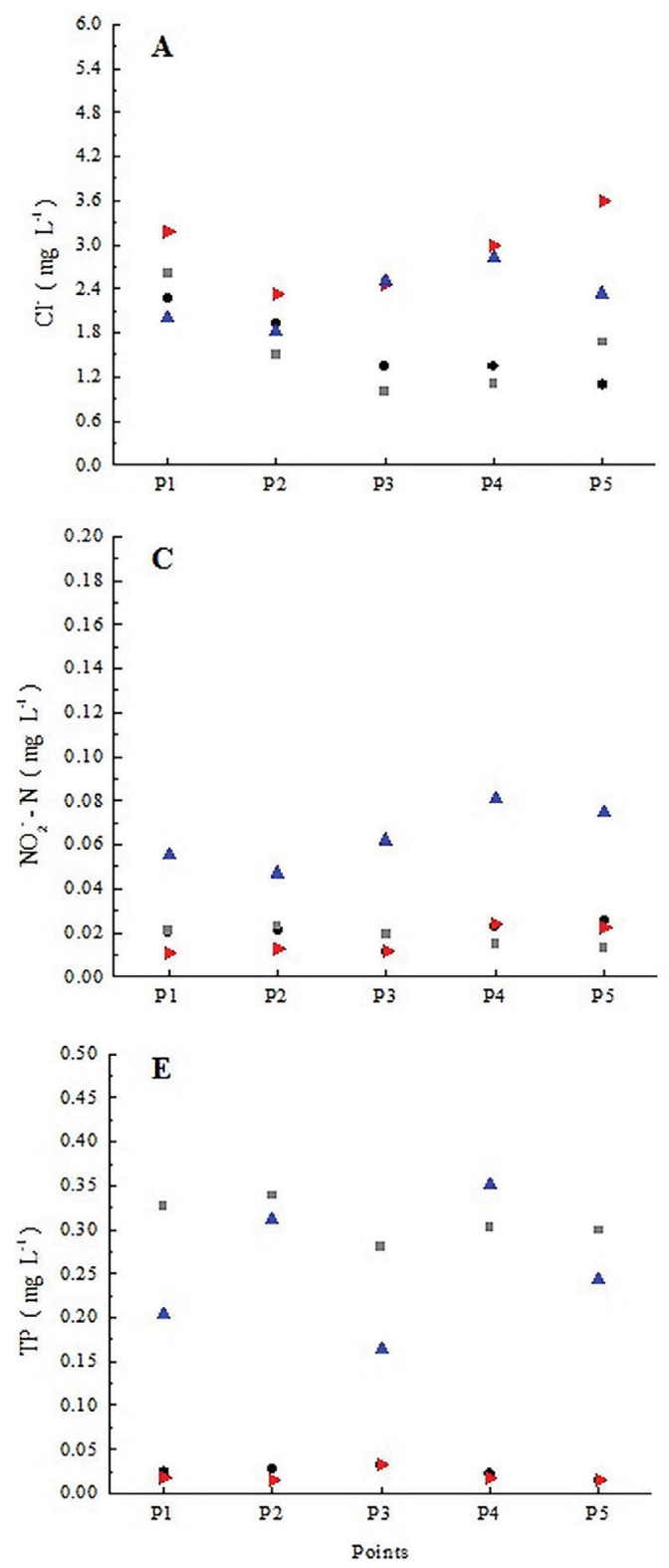

of dissolved solids in the water bodies increases, as observed in the present study. The greatest values for TDS and EC in C2 are possibly related to the transport of soluble and ionizable material in aqueous medium (present in the drainage basin soil) and carried to the stream due to the occurrence of precipitation during the three days before $\mathrm{C} 2$, which did not occur at the time of the other collections.
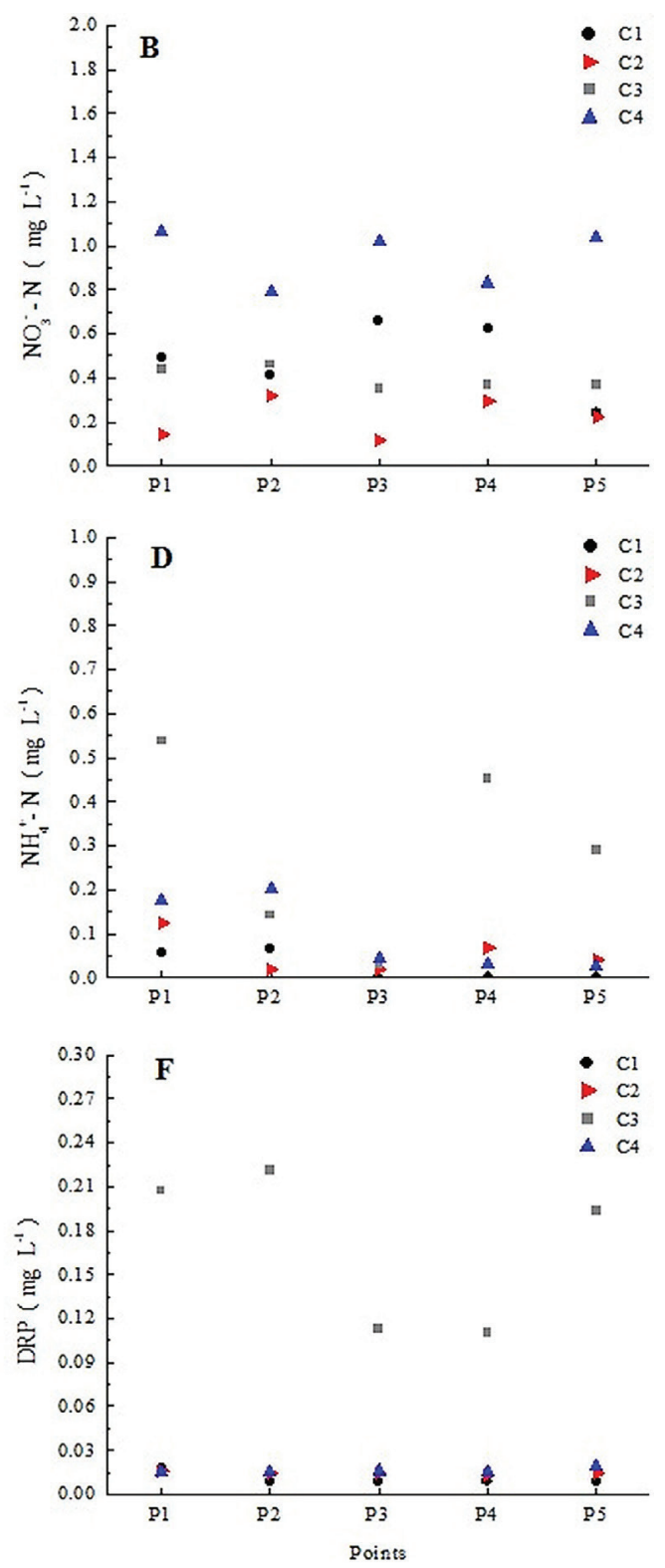

Figure 4: Arithmetic means of the following variables: (A) $\mathrm{Cl}^{-}$(chloride), (B) $\mathrm{NO}_{3}^{-}-\mathrm{N}$ (nitrate), (C) $\mathrm{NO}_{2}^{-}-\mathrm{N}$ (nitrite), (D) $\mathrm{NH}_{4}{ }^{+}-\mathrm{N}$ (ammoniacal nitrogen), (E) TP (total phosphorus) and (F) DRP (dissolved reactive phosphorus). 
Turbidity values were below the thresholds established by CONAMA resolution 357/2005 (Table 1), with the exception of points 2 (124.7 NTU) and 3 (136.7 NTU) of C4 (Figure 3). This could be due the presence of some particles observed during sampling at point 2, and the presence of oils and greases observed at point 3 , where there was a motor pump for water collection for irrigation of the vegetable garden. The average results from $\mathrm{C} 4$ were significantly different from the averages of $\mathrm{C} 1$ and $\mathrm{C} 2$ (Table 3 ).

Table 2: Mean square for the physical and chemical variables in ANOVA.

\begin{tabular}{|c|c|c|c|c|c|}
\hline Variables & Collection & Points & Residue & Average & CV (\%) \\
\hline $\mathrm{pH}$ & $0.17 *$ & $0.82^{* *}$ & 0.05 & 6.49 & 3.35 \\
\hline $\mathrm{DO}\left(\mathrm{mg} \mathrm{L}^{-1}\right)$ & $4.86^{\mathrm{ns}}$ & $1.41^{\mathrm{ns}}$ & 1.62 & 6.63 & 19.22 \\
\hline $\mathrm{EC}\left(\mu \mathrm{S} \mathrm{cm^{-1 } )}\right.$ & $5,127.19 * *$ & $311.27^{\mathrm{ns}}$ & 158.96 & 67.76 & 18.61 \\
\hline $\operatorname{TDS}\left(\mathrm{mg} \mathrm{L}^{-1}\right)$ & $2,056.13^{* *}$ & $134.77^{\text {ns }}$ & 75.07 & 43.56 & 19.89 \\
\hline Turbidity (NTU) & $0.02 * *$ & $0.003^{\text {ns }}$ & 0.002 & 0.28 & 17.76 \\
\hline ORP $(m V)$ & $7,031.82 * \star$ & $18,199.11^{* *}$ & $1,029.30$ & 154.75 & 20.73 \\
\hline $\mathrm{Cl}^{-}\left(\mathrm{mg} \mathrm{L}^{-1}\right)$ & $2.03 * *$ & $0.29^{\text {ns }}$ & 0.26 & 2.09 & 24.41 \\
\hline $\mathrm{NO}_{2}^{-}-\mathrm{N}\left(\mathrm{mg} \mathrm{L}^{-1}\right)$ & $0.002 * *$ & $0.000^{\mathrm{ns}}$ & 0.000 & 0.030 & 27.34 \\
\hline $\mathrm{NO}_{3}^{-}-\mathrm{N}\left(\mathrm{mg} \mathrm{L}^{-1}\right)$ & $0.480 * \star$ & $0.003^{\text {ns }}$ & 0.020 & 0.510 & 25.35 \\
\hline $\mathrm{NH}_{4}^{+}-\mathrm{N}\left(\mathrm{mg} \mathrm{L}^{-1}\right)$ & $0.030 * *$ & $0.009^{n s}$ & 0.004 & 0.790 & 8.74 \\
\hline $\mathrm{TP}\left(\mathrm{mg} \mathrm{L}^{-1}\right)$ & $0.11 * *$ & $0.001^{\mathrm{ns}}$ & 0.002 & 0.15 & 26.45 \\
\hline $\operatorname{DRP}\left(\mathrm{mg} \mathrm{L}^{-1}\right)$ & $0.036 * \star$ & $0.009^{\text {ns }}$ & 0.015 & 0.051 & 60.81 \\
\hline
\end{tabular}

CV: coefficient of experimental variation. $\mathrm{pH}$ : hydrogen potential. DO: dissolved oxygen. EC: electrical conductivity. TDS: total

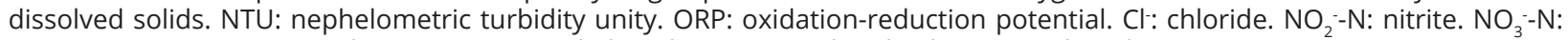
nitrate. $\mathrm{NH}_{4}{ }^{+}-\mathrm{N}$ : ammoniacal nitrogen. TP: total phosphorus. DRP: dissolved reactive phosphorus.

${ }^{n s}$ not significant at the 0.05 level; *Significant at the 0.05 level; **Significant at the 0.01 level.

Table 3: Variables that showed significance among the collections.

\begin{tabular}{|c|c|c|c|c|}
\hline \multirow[t]{2}{*}{ Variables } & \multicolumn{4}{|c|}{ Collections } \\
\hline & 1 & 2 & 3 & 4 \\
\hline $\mathrm{pH}$ & $6.41 \mathrm{ab}$ & 6.71 & 6.29 & $6.57 \mathrm{ab}$ \\
\hline $\mathrm{EC}\left(\mu \mathrm{S} \mathrm{cm} \mathrm{cm}^{-1}\right)$ & $65.76 \mathrm{~b}$ & 113.20 & 40.40 & $65.76 \mathrm{~b}$ \\
\hline TDS (mg L-1) & $42.40 \mathrm{~b}$ & 72.40 & 26.73 & $32.73 \mathrm{~b}$ \\
\hline Turbidity (NTU) & $0.32 a$ & 0.35 & $0.27 \mathrm{ab}$ & $0.20 \mathrm{~b}$ \\
\hline $\mathrm{ORP}(\mathrm{mV})$ & $137.40 \mathrm{~b}$ & 124.33 & 148.20 & $209.06 a$ \\
\hline $\mathrm{Cl}^{-}\left(\mathrm{mg} \mathrm{L}^{-1}\right)$ & $1.59 \mathrm{~b}$ & 2.90 & 1.57 & $2.30 \mathrm{ab}$ \\
\hline $\mathrm{NO}_{2}^{-}-\mathrm{N}\left(\mathrm{mg} \mathrm{L}^{-1}\right)$ & $0.02 \mathrm{~b}$ & $0.02 k$ & 0.02 & $0.06 a$ \\
\hline $\mathrm{NO}_{3}^{-}-\mathrm{N}\left(\mathrm{mg} \mathrm{L}^{-1}\right)$ & $0.49 \mathrm{~b}$ & 0.22 & 0.41 & $0.95 a$ \\
\hline $\mathrm{NH}_{4}^{+}-\mathrm{N}\left(\mathrm{mg} \mathrm{L}^{-1}\right)$ & $0.72 \mathrm{~b}$ & 0.74 & 0.91 & $0.77 \mathrm{~b}$ \\
\hline $\mathrm{TP}\left(\mathrm{mg} \mathrm{L}^{-1}\right)$ & $0.02 \mathrm{~b}$ & $0.02 k$ & 0.31 & $0.26 \mathrm{a}$ \\
\hline $\mathrm{DRP}\left(\mathrm{mg} \mathrm{L}^{-1}\right)$ & $0.012 b$ & $0.012 k$ & 0.17 & $0.016 \mathrm{~b}$ \\
\hline
\end{tabular}

$\mathrm{pH}$ : hydrogen potential. EC: electrical conductivity. TDS: total dissolved solids. NTU: nephelometric turbidity unity. ORP: oxidation-reduction potential. $\mathrm{Cl}$ : chloride. $\mathrm{NO}_{2}^{-}-\mathrm{N}$ : nitrite. $\mathrm{NO}_{3}^{-}-\mathrm{N}$ : nitrate. $\mathrm{NH}_{4}^{+}-\mathrm{N}$ : ammoniacal nitrogen. TP: total phosphorus. DRP: dissolved reactive phosphorus.

Means followed by the same letter in rows do not differ statistically by Tukey's test at the 0.05 level. 
Table 4: Variables that showed significance among the points.

\begin{tabular}{|c|c|c|}
\hline Points & $\mathrm{pH}$ & ORP $(\mathrm{mV})$ \\
\hline P1 & $7.21 \mathrm{a}$ & $60.08 \mathrm{~b}$ \\
\hline P2 & $6.58 \mathrm{~b}$ & $109.58 \mathrm{~b}$ \\
\hline P3 & $6.45 \mathrm{~b}$ & $185.00 \mathrm{a}$ \\
\hline P4 & $6.14 \mathrm{c}$ & $197.75 a$ \\
\hline P5 & $6.06 \mathrm{c}$ & $221.33 a$ \\
\hline
\end{tabular}

pH: hydrogen potential. ORP: oxidation-reduction potential.

Means followed by the same letter in columns do not differ statistically by Tukey's test at a 0.05 significance level.

Although the presence of $\mathrm{Cl}^{-}$in freshwater can be from natural sources (weathering of rocks, for example), increased population and road density, solid waste incineration and intensification of agriculture are the main sources of $\mathrm{Cl}^{-}$. Therefore, manure applied to cultivated land and the weathering of soil both contribute to chloride transfer from soil to surface waters (Müller; Gatcher, 2012). In this work, the highest $\mathrm{Cl}^{-}$concentration was $3.60 \mathrm{mg} \mathrm{L}^{-1}$, observed for point 5 in C2. In general, C2 samples had the highest values, followed by $\mathrm{C} 4$ samples. The average concentration of $\mathrm{Cl}^{-}$in the points from all samplings (Figure 4) was below the established thresholds according to current legislation (Table 1). In addition, we must consider that the levels of $\mathrm{Cl}^{-}$were not exclusively influenced by farming activities but also by climatic factors in association with the hydrological cycle.

Possibly, the higher concentrations of $\mathrm{Cl}^{-}$observed in $\mathrm{C} 2$ are also related to the transport of soluble and ionizable material in aqueous medium (present in the drainage basin soil) and carried to the stream due to the occurrence of precipitation during the three days before $\mathrm{C} 2$. On the other hand, the elevation of the chloride concentration observed in $\mathrm{C} 4$ may be due to the occurrence of dry climate at the time of this collection. There was a predominance of chloride found in Apodi pond water (Rio Grande do Norte, Brazil), which could be explained by the dry season due to the occurrence of high evaporation in the water body (Lemos; Ferreira Neto; Dias, 2010). Moreover, in the literature there are reports of the occurrence of high $\mathrm{Cl}^{-}$concentrations during the summer season compared to the monsoon and winter seasons (Brraich; Saini, 2015).

The nutrients nitrogen and phosphorus are the main cause of water contamination due to leaching from agricultural soils to streams (Lewis; Wurtsbaugh, 2008). According to Brraich and Saini (2015) phosphate acts as an important regulating factor for productivity of water bodies, and there are a few natural sources of phosphate.
The main anthropogenic phosphate sources for water bodies are domestic waste, detergents and agricultural run-off containing fertilizer.

In our study, although the TP contents in the samples do not vary among the points we can observe differences among the collections. The last two samplings ( $\mathrm{C} 3$ and C4) showed the highest levels of TP at all points (Figure 4) that was about three times the recommended limit set by environmental legislation in Brazil $\left(0.10 \mathrm{mg} \mathrm{L}^{-1}\right)$ and 15 times the TP content at $\mathrm{C} 1$ and $\mathrm{C} 2\left(0.02 \mathrm{mg} \mathrm{L}^{-1}\right)$. The largest concentration of DRP was observed in water sampled in C3 (Figure 4). Although CONAMA 357/2005 does not specify a maximum value for this variable, limnological studies should consider this quantification because it is the main form of phosphorus assimilated by aquatic plants (Dias; Sipaúba-Tavares, 2012). The presence of this form of phosphate in the water depends on the density and activity of organisms, such as phytoplankton and aquatic macrophytes (King et al., 2014). In unpolluted waters, this ability of phytoplankton and aquatic plants commonly results in lower DRP concentrations than $0.02 \mathrm{mg} \mathrm{L}^{-1}$ near the surface of the body of water (Libânio, 2010). The levels of DRP in C3 exceeded up to 10 times the limit of $0.02 \mathrm{mg} \mathrm{L}^{-1}$.

In the evaluation of spatial and temporal variation of water quality along the Paraitinga River, a tributary of the Tietê River at São Paulo State (Brazil), the highest concentrations of TP (of the order of $0.1 \mathrm{mg} \mathrm{L}^{-1}$ ) were observed in the rainy season at pasture regions (Esteves; Lôbo; Hilsdorf, 2015). However, in the present work, the year in which C3 and C4 were carried out (2014) presented an atypical and very dry climate (Figure 2). This characteristic may have led to an increase in the content of particulate phosphorus (insoluble forms of $\mathrm{P}$, suspended) in the body of water, justifying the highest values observed for TP in the last two collections and for DRP in the penultimate collection. Considering the above and the fact that the TP corresponds to the sum of the particulate, dissolved, organic and inorganic fractions of $\mathrm{P}$, it is possible to verify that in the 
C3 water samples the DRP corresponds to a considerable fraction of the TP while in C4 the DRP possibly does not represent large part of the TP.

Point sources of $\mathrm{P}$ (wastewaters and industrial effluents) are highly concentrated in soluble $\mathrm{P}$ and diffuse sources, which are sources always linked with agriculture, have a greater proportion in particulate form $(>4.5 \mu \mathrm{m})$, arrive only during storm events in surface and sub-surface runoff and from a number of scattered entry points within the catchment. In addition to these sources, there are a number of individual sources (road and track runoff, septic tank discharges and farmyard runoff) that have characteristics intermediate between those of point and diffuse sources (Withers; Jarvie, 2008).

Jarvie, Neal and Withers (2006), studied P concentrations from water quality monitoring at 54 UK river sites across seven major lowland catchment systems observed that the highest DRP concentrations occur during the summer period, when river flows are lowest and eutrophication risks are highest. Furthermore, monitoring data has indicated that point sources of phosphorus provide a greater risk for river eutrophication than diffuse sources from agricultural land, even for rural areas with high agricultural phosphorus losses.

Ammonium $\left(\mathrm{NH}_{4}^{+}\right)$and ammonia $\left(\mathrm{NH}_{3}\right)$ are chemical forms of ammoniacal nitrogen. The predominance of either of two species in aqueous media will depend on the $\mathrm{pH}$ value. At higher $\mathrm{pH}, \mathrm{NH}_{3}$ will predominate, and this form is toxic to fish and other organisms (Garg; Rao; Saksena, 2009). In our work, the $\mathrm{pH}$ of the studied stream favors the predominance of ammonium ions (which is less toxic than $\mathrm{NH}_{3}$ ), and these concentrations were below the legal limit (Table 1). The largest concentrations of $\mathrm{NH}_{4}^{+}-\mathrm{N}$ were observed in $\mathrm{C} 3$ (Figure 4). $\mathrm{NO}_{3}^{-}-\mathrm{N}$ and $\mathrm{NO}_{2}^{-}-\mathrm{N}$ concentrations showed the highest levels at $\mathrm{C} 4$ (Figure 4). For all samplings $\mathrm{NO}_{2}^{-}-\mathrm{N}$ and $\mathrm{NO}_{3}^{-}-\mathrm{N}$ contents were lower than the maximum values allowed by current legislation (Table 1).

We observed concentrations of $\mathrm{NO}_{3}^{-}-\mathrm{N}$ slightly exceeding $1 \mathrm{mg} \mathrm{L}^{-1}$ only in $\mathrm{C} 4$ (the greatest values among the averaged points), followed by $\mathrm{C} 1$ and $\mathrm{C} 3$, which did not differ statistically ( $\mathrm{p}$-value $<0.05$ ) from each other, while the lowest values were found in $\mathrm{C} 2$. One of the main sources of nitrogen for the water bodies is leaching of the soil by increasing rainfall indices (Sipaúba-Tavares; Guariglia; Braga, 2007), and this could explain the results observed for nitrate in $\mathrm{C} 1$. In rainy seasons there are higher concentrations of $\mathrm{NO}_{2}^{-}-\mathrm{N}$ and $\mathrm{NO}_{3}^{-}-\mathrm{N}$ in aquatic environments due to rain action as a diffusing source (Silva et al., 2009).
It is not possible to state that the organic compost and/or mineral fertilizers applied in the farm's vegetable garden are responsible for the results observed in the last two collections, since, as already mentioned, there was no statistical difference for TP, DRP and $\mathrm{N}$ forms among the points of the four sampling performed. It should also be considered that the area of the studied stream presents, besides the vegetable garden of the zoo, agricultural activities (such as planting corn) in other rural properties present in its surroundings. In addition, although pollution from soil management can influence water quality, either by discharge of irrigation or drainage water and by leaching, other pathways are possible. In this way it can not be excluded that upstream of P1 (Figure 1) there is a public water supply plant that can produce effluents with high concentrations of (often impure) chemicals used in the treatment process (Rocha; Rosa; Cardoso, 2009).

In summary, all of the physical variables and most chemical variables studied in this work were below the thresholds defined by current legislation, and it suggests that the water from all studied points along the stream have suitable quality for the irrigation of vegetables. Briefly, we have that: by the chemical and physical analysis results, no correlation can be made between the application of the organic compost in the garden area and any parameter studied.

\section{Microbiological parameters}

One of the microbiological parameters for water quality is the presence of total coliforms and E. coli. These parameters are some of the most important environmental contamination indicators (Paruch; Maehlum, 2012). Our microbiological tests were carried out to determine the presence of these microorganisms (Table 5).

A higher incidence of total coliforms was observed in the samples from $\mathrm{C} 1$ and $\mathrm{C} 2$, coinciding with the greatest rainfall period $(\mathrm{C} 1)$ or a date collection near rainfall $(\mathrm{C} 2)$. Water contamination by this microbial community is derived from animal waste sources, so it is necessary to monitor and assess the concentration of these microorganisms (Rodrigues et al., 2011). Coliform concentration tends to have a direct relationship with rainfall levels (Cha et al., 2010), and this could explain the higher incidence of total coliforms in the period with the highest rainfall. Total coliforms do not indicate recent fecal contamination or presence of enteropathogenic bacteria, as a large portion of these microorganisms may be present in soil or plants undergoing decomposition (Lemos; Ferreira Neto; Dias, 2010). 
Table 5: Most probable number (MPN) of total coliforms and E. coli in points of the four collections.

\begin{tabular}{cccccc}
\hline & \multicolumn{3}{c}{ Total Coliforms/E. coli } & P4 & P5 \\
\hline Collection & P1 & P2 & P3 & $221 / 0$ & $135 / 0$ \\
C1 & $165 / 0$ & $152 / 0$ & $131 / 0$ & $130 / 0$ & $112 / 0$ \\
C2 & $140 / 1$ & $160 / 2$ & $120 / 0$ & $73 / 1$ & $55 / 1$ \\
C3 & $20 / 0$ & $45 / 2$ & $106 / 0$ & $55 / 3$ & $66 / 8$ \\
C4 & $154 / 6$ & $112 / 7$ & $46 / 9$ & \\
\hline
\end{tabular}

Data presented in MPN/100 mL.

The presence of $E$. coli was not observed in the samples of water from the first sampling but was detected in the other samplings. Martins et al. (2013), in their study of the microbial diversity of the organic compost used in the vegetable garden of the FPZSP, found a low relative abundance of organisms belonging to the family Enterobacteriaceae. However, we cannot determine whether this microbial contamination occurred through leaching from the vegetable garden because there are other factors that could also explain the observed bacteria, such as the presence of wild animals near the site. In addition, the fourth collection period (C4) comprises a long period of drought and higher temperatures, which favors the appearance of animals for watering. In these samples, the largest numbers of $E$. coli were observed. On the other hand some strains of $E$. coli contain virulence genes, such as stx1, stx2 and eae, which impact human or animal health (Borges et al., 2012). We used PCR to assess the presence or absence of these genes in the samples, and these genes were not detected in any of the analyzed samples.

To investigate the metabolic profile of the bacterial communities in the environment, Biolog EcoPlate assays with carbon substrates were used to evaluate the metabolic potential of microbial degradation of some substrates in each sampled point. This technique is not widely used in studies involving water quality; however, it is very informative and useful to evaluate microbial functional diversity. In the exploratory data analysis using hierarchical clustering, it was apparent that the environment is characterized by a great diversity of carbon source consumption (Figure 5), likely due to great diversity of microbial populations. Recent analyses from soil and water using EcoPlate and bacterial population show a correlation among carbon consumption and changes in microbial population (Boras et al., 2015; Wang et al., 2016).
In general, the environment was characterized as diverse in function, as shown by the index values in Table 6. There was a greater diversity in the fourth sampling as well as a greater number of substrates consumed. This suggests that the environment was balanced, despite possible leaching from the soil and/ or organic compost. Moreover, the second sampling (C2) showed similarity within itself for all sampling points, differing only from other samplings and their respective points. This occurrence can be explained by the fact that in the second collection was characterized by an extremely dry season with intense heat, but light incidence of rain two days before the sampling unlike the other three periods. Recently, Pommier et al. (2014) observed a significantly increased amount of dissolved organic carbon in the leachate from agricultural soil amended with compost and vermicompost compared to un-amended soil. They also observed that leachates from these amended soils were highly bioavailable to aquatic microbiota, reducing the metabolic potential of the microbial community and harboring specific communities.

According to our EcoPlate results, we cannot observe a decrease in the metabolic potential of bacterial communities in freshwater samples collected from the stream. This could be partly explained by the presence of riparian vegetation along the stream, which represents a physical barrier against leachates derived from agricultural soil. Moreover, this buffer zone could also be another source of energy and nutrients for stream communities. We can observe too that all points of the $\mathrm{C} 2$ sampling were grouped as an isolated cluster. The rainfall before the second collection may have caused a slight change in the microbial population in the water, but this interference would not be related to the use of the organic compost in the garden. 


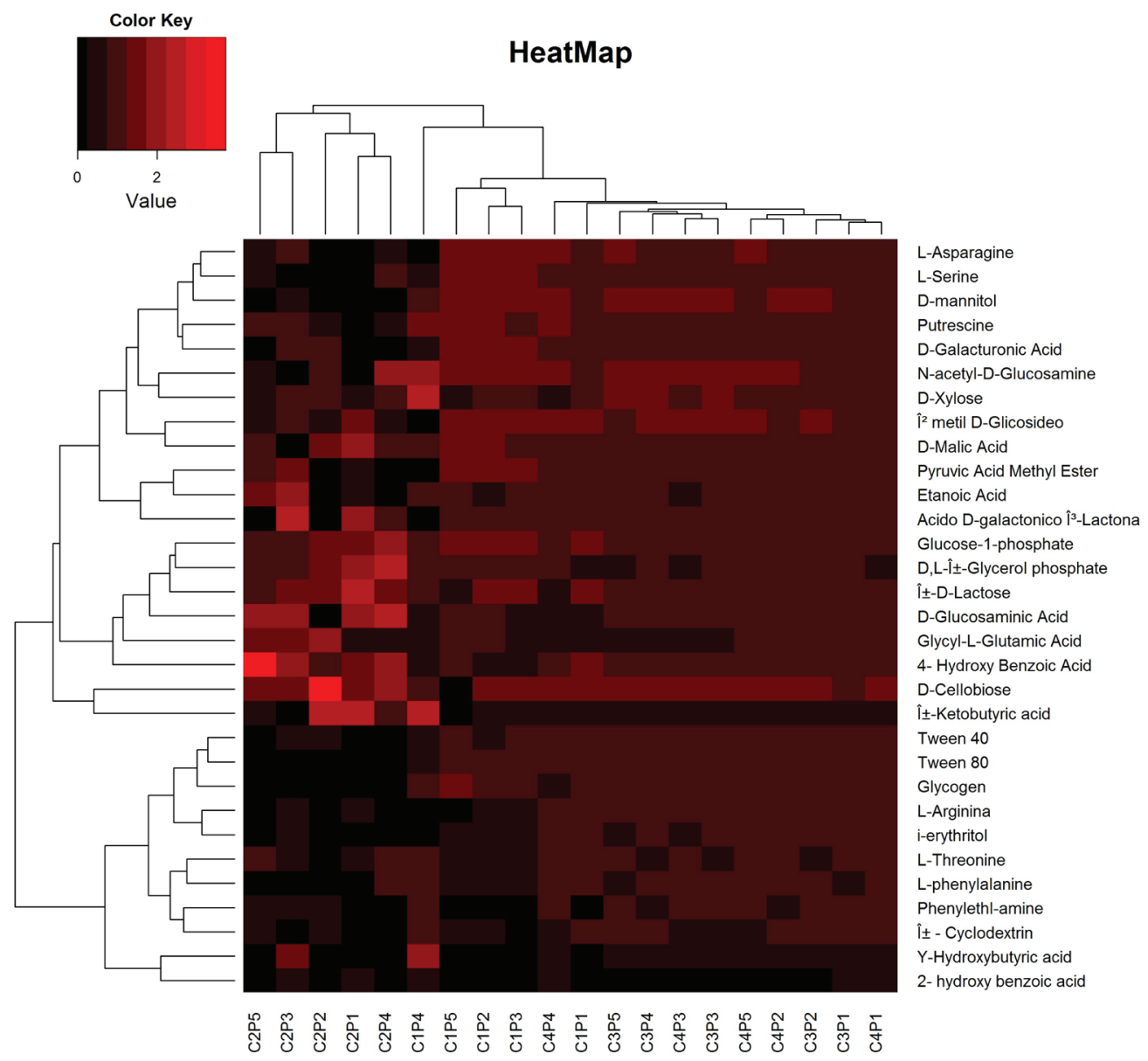

Figure 5: Heatmap for the four collections carried out using the 31 carbon sources from Biolog EcoPlate.

Table 6: The substrate richness (Sr), average well color development (AWCD) and Shannon diversity index (H) calculated from EcoPlate after $120 \mathrm{~h}$ of incubation.

\begin{tabular}{ccccccc}
\hline Collection & & $\mathrm{P} 1$ & $\mathrm{P} 2$ & $\mathrm{P} 3$ & $\mathrm{P} 4$ & $\mathrm{P5}$ \\
\hline \multirow{2}{*}{1} & $\mathrm{Sr}$ & 28 & 28 & 30 & 14 & 30 \\
& $\mathrm{AWCD}$ & 0.85 & 1.54 & 1.52 & 0.09 & 1.45 \\
& $\mathrm{H}$ & 3.35 & 3.31 & 3.34 & 2.45 & 3.32 \\
\hline \multirow{2}{*}{2} & $\mathrm{Sr}$ & 9 & 3 & 16 & 11 & 10 \\
& $\mathrm{AWCD}$ & 0.01 & 0.05 & 0.02 & 0.02 & 0.01 \\
& $\mathrm{H}$ & 2.72 & 2.51 & 3.02 & 2.84 & 2.44 \\
\hline & $\mathrm{Sr}$ & 29 & 29 & 30 & 30 & 30 \\
& $\mathrm{AWCD}$ & 1.89 & 1.96 & 1.34 & 1.95 & 1.77 \\
& $\mathrm{H}$ & 3.44 & 3.43 & 3.41 & 3.41 & 3.38 \\
\hline & $\mathrm{Sr}$ & 31 & 31 & 29 & 31 & 30 \\
& $\mathrm{AWCD}$ & 1.88 & 1.82 & 1.82 & 1.86 & 1.91 \\
& $\mathrm{H}$ & 3.44 & 3.43 & 3.42 & 3.42 & 3.44 \\
\hline
\end{tabular}




\section{CONCLUSIONS}

The physical, chemical and microbiological parameters studied suggest that the use of the organic compost produced with vegetal and animal waste by the FZSP does not negatively influence the surface water quality of the studied area. Although it was not yet possible to reach a definitive conclusion regarding all environmental impacts in this work considering the low numbers of sampling, but we could not find strong evidence to assert otherwise with the current analyses. Moreover, this conclusion was made considering the viability of the composting process and organic compost as an economic alternative to maintain productivity while reducing the use of mineral fertilizers, which we know are strongly related with water pollution. This approach also appears to be a sustainable solution to decrease negative environmental impacts related to inappropriate waste disposal. This was the first study carried out in this agricultural environment using a highly sustainable organically produced vegetable and animal waste compost. Other studies with an environmental monitoring and water quality control will be able to provide more information about the environmental safety by the use of this product. Furthermore, new tools for microbiological community study, as metagenomic approaches are required for detailed exploration of the microbial populations in this aquatic environment as well as in the soil from the vegetable garden.

\section{ACKNOWLEDGEMENTS}

We thank São Paulo Research Foundation (FAPESP 2013/08729-0), National Council of Technological and Scientific Development (CNPq 478347/2013-8), Coordination for the Improvement of Higher Education Personnel (CAPES), Postgraduate Program in Microbiologia Agropecuária from FCAV/ UNESP, São Paulo Zoo Park Foundation (FPZSP), the Agronomist Sergio E. Saliba and the staff of the São Paulo Zoo Farm.

\section{REFERENCES}

ASKEW, E. F.; SMITH, R. K. (Coord.). Inorganic nonmetallic constituents. In: EATON, A. D. et al. (ed.). Standard methods for the examination of water \& wastewater. 21. ed. Washington, DC: American Public Health Association, APHA, 2005, p.1-192.
AYERS, R. S.; WESTCOT, D. W. Water quality for agriculture. FAO irrigation and drainage paper 29, Rev. 1. Rome, Italy: Food and Agricultural Organization of the United Nations (FAO), 1994. Available in: <http://www.fao.org/docrep/003/ T0234E/T0234E01.htm\#ch1> Access in: September, 2, 2016.

BAKER, M. L. (Coord.). Introduction. In: EATON, A. D. et al. (ed.). Standard methods for the examination of water \& wastewater. 21. ed. Washington, DC: American Public Health Association (APHA), 2005, p.1-56.

BORAS, J. A. et al. Factors shaping bacterial phylogenetic and functional diversity in coastal waters of the NW Mediterranean Sea. Estuarine, Coastal and Shelf Science, 154:102-110, 2015.

BORGES, C. A. et al. Shiga toxigenic and atypical enteropathogenic Escherichia coli in the feces and carcasses of slaughtered pigs. Foodborne Pathogens and Disease, 9(12):1119-1125, 2012.

BRASIL. Ministério do Meio Ambiente. Conselho Nacional do Meio Ambiente. Resolução CONAMA No 357/2005, de 17 março de 2005. Available in: <http://www.mma.gov.br/ port/conama/> Access in: September, 2, 2016.

BRRAICH, O. S.; SAINI, S. K. Water quality index of Ranjit Sagar wetland situated on the Ravi River of Indus River system. International Journal of Advanced Research, 3(12):14981509, 2015.

CANCELADO, S. V. et al. Microbiological quality assessment of a compost produced from animal waste and vegetables. The Sustainable City IX, 2:1469-1479, 2014.

CETESB. Companhia Ambiental do Estado de São Paulo. Enquadramento dos Corpos Hídricos - Mapas Temáticos. 2017. Available in: <http://aguasinteriores.cetesb. sp.gov.br/enquadramento-dos-corpos-hidricos-mapastematicos/> Access in: January, 1, 2017.

CHA, S. et al. Spatial and temporal variability of fecal indicator bacteria in an urban stream under different meteorological regimes. Water Science \& Technology, 61(12):3102-3108, 2010.

CHÁVEZ, L. F. et al. Diversidade metabólica e atividade microbiana no solo em sistema de integração lavourapecuária sob intensidades de pastejo. Pesquisa Agropecuária Brasileira, 46(10):1254-1261, 2011.

CHINA, B.; PIRSON, V.; MAINIL, J. Typing of bovine attaching and effacing Escherichia coli by multiplex in vitro amplification of virulence-associated genes. Applied and Environmental Microbiology, 62(9):3462-3465, 1996. 
CORCÓVIA, J. A.; CELLIGOI, A. Avaliação preliminar da qualidade da água subterrânea no município de Ibiporã-PR. Revista de Estudos Ambientais, 14(2):39-48, 2012.

DIAS, S. G.; SIPAÚBA-TAVARES, L. H. Physical, chemical and microbiological aspects during the dry and rainy seasons in a pond covered by macrophyte used in aquaculture water supply. Acta Limnologica Brasiliensia, 24(3):276-284, 2012.

ESTEVES, K. E.; LÔBO, A. V. P.; HILSDORF, A. W. S. Abiotic features of a river from the Upper Tietê River Basin (SP, Brasil) along an environmental gradient. Acta Limnologica Brasiliensia, 27(2):228-237, 2015.

GARG, R. K.; RAO, R. J.; SAKSENA, D. N. Water quality and conservation management of Ramsagar reservoir, Datia, Madhya Pradesh. Journal of Environmental Biology, 30(5):909-916, 2009.

GARLAND, J. L.; MILLS, A. L. Classification and characterization of heterotrophic microbial communities on the basis of patterns on community-level, sole carbono-source utilization. Applied and Environmental Microbiology, 57:2351-2359, 1991.

HACKETT, C. A.; GRIFFITHS, B. S. Statistical analysis of the time-course of biology substrate utilization. Journal of Microbiological Methods, 30(1):63-69, 1997.

HUNT, M. E.; RICE, E. W. (Coord.). Microbiological examination. In: EATON, A. D. et al. (ed.). Standard methods for the examination of water \& wastewater. 21.ed. Washington, DC: American Public Health Association, APHA, 2005, p.1-169.

IBEKWE, A. M.; KENNEDY, A. C. Phospholipid fatty acid profiles and carbon utilization patterns for analysis of microbial community structure under field and greenhouse conditions. FEMS Microbiology Ecology, 26(2):151-163, 1998.

INSTITUTO NACIONAL DE METEREOLOGIA - INMET. Ministério da Agricultura, Pecuária e Abastecimento. BDMEP - Banco de dados meteorológicos para ensino e pesquisa. Available in: < http://www.inmet.gov.br/portal/index. php?r=bdmep/bdmep $>$ Access in: January, 1, 2017.

JARVIE, H. P.; NEAL, C.; WITHERS, P. J. A. Sewage-effluent phosphorus: A greater risk to river eutrophication than agricultural phosphorus? Science of the Total Environment, 360:246-253, 2006.

JORDAN, Y. C.; GHULAM, A.; HARTLING, S. Traits of surface water pollution under climate and land use changes: A remote sensing and hydrological modeling approach. Earth-Science Reviews, 128:181-195, 2013.
KING, K. W. et al. Phosphorus transport in agricultural subsurface drainage: A review. Journal of Environmental Quality, 44(2):467-485, 2014.

KÜLCÜ, R.; YALDIZ, O. The composting of agricultural wastes and the new parameter for the assessment of the process. Ecological Engineering, 69:220-225, 2014.

LEMOS, M.; FERREIRA NETO, M.; DIAS, N. S. Sazonalidade e variabilidade espacial da qualidade da água na Lagoa do Apodi, RN. Revista Brasileira Engenharia Agrícola e Ambiental, 14(2):155-164, 2010.

LEWIS, W. M.; WURTSBAUGH, W. A. Control of lacustrine phytoplankton by nutrients: Erosion of the phosphrous paradigm. International Review of Hydrobiology, 93(4-5):446-465, 2008.

LIBÂNIO, M. Fundamentos de qualidade e tratamento de água. 3. ed. Campinas, SP: Editora Átomo, 2010. 494p.

LIM, S. L. et al. The use of vermicompost in organic farming: Overview, effects on soil and economics. Journal of the Science of Food and Agriculture, 95(6):1143-1156, 2015.

MARTINS, L. F. et al. Metagenomic analysis of a tropical composting operation at the São Paulo Zoo Park reveals diversity of biomass degradation functions and organisms. PLOS ONE, 8(4):1-13, 2013.

MÜLLER, B.; GÄCHTER, R. Increasing chloride concentrations in Lake Constance: Characterizarion of sources and estimation of loads. Aquatic Sciences, 74(1):101-112, 2012.

OGUNDARE, M. O.; LABUNMI, L. Physico-chemical and mineral analysis of composts fortified with NPK fertilizer, ammonium chloride and kaolin. Journal of Agricultural Chemistry and Environment, 2(2):27-33, 2013.

PARUCH, A. M.; MAEHLUM, T. Specific features of Escherichia coli that distinguish it from coliform and thermotolerant coliform bacteria and define it as the most accurate indicator of faecal contamination in the environment. Ecological Indicators, 23:140-142, 2012.

POMMIER, T. et al. Off-site impacts of agricultural composting: Role of terrestrially derived organic matter in structuring aquatic microbial communities and their metabolic potential. FEMS Microbiology Ecology, 90:622-632, 2014.

ROCHA, J. C.; ROSA, A. H.; CARDOSO, A. A. Introdução à química ambiental, 2. ed. Porto Alegre: Bookman, 2009. 256p.

RODRIGUES, M. et al. Modeling fecal contamination in the Aljezur coastal stream (Portugal). Ocean Dynamics, 61:841-856, 2011. 
SAS INSTITUTE. SAS/STAT user's guide. Version 9.1.3. Cary: SAS Institute. 2008.

SECCHI, S. et al. Potential water quality changes due to corn expansion in the Uper Mississipi Riber Basin. Ecological Applications, 21:1068-1084, 2011.

SHELTON, D. R. et al. Response of coliform populations in streambed sediment and water column to changes in nutrient concentrations in water. Water Research, 59:316-324, 2014.

SHUSTER, W. D. et al. Assessment of residential rain barrel water quality and use in Cincinnati, Ohio. Journal of the American Water Resources Association, 49(4):753-765, 2013.

SILVA, G. S. et al. Phosphorus and nitrogen in waters of the Ocoí River sub-basin, Itaipu reservoir tributary. Journal of the Brazilian Chemical Society, 20(9):1580-1588, 2009.

SIPAÚBA-TAVARES, L. H.; GUARIGLIA, C. S. T.; BRAGA, F. M. $S$. Effects of rainfall on water quality in six sequentially disposed fishponds with continuous water flow. Brazilian Journal of Biology, 67(4):643-649, 2007.
WANG, Z. et al. The microbiome and functions of black soils are altered by dibutyl phthalate contamination. Applied Soil Ecology, 99:51-61, 2016.

WEINDORF, D. C.; MUIR, J. P.; LANDERO-SÁNCHES, C. Organic compost and manufactured fertilizers: Economics and ecology. In: CAMPBELL, W. B.; ORTíZ, S. L. (ed.). Integrating agriculture, conservation and ecotourism: Examples from the field. New York: Springer, 2011, p. 27-53.

WITHERS, P. J. A.; JARVIE, H. P. Dlivery and cycling phosphorus in rivers: A review. Science of the Total Environment, 400: 379-395, 2008.

ZAK, J. C. et al. Functional diversity microbial communities: A quantitative approach. Soil Biology and Biochemistry, 26(9):1101-1108, 1994.

ZHAO, J. et al. Influences of land use on water quality in a reticular river network area: A case study in Shanghai, China. Landscape and Urban Planning, 137:20-29, 2015. 